\title{
EFEKTIVITAS BALI GO LIVE SEBAGAI MEDIA PROMOSI DIGITAL PARIWISATA BALI
}

\author{
Ni Luh Putu Septiani ${ }^{1}$, I Nyoman Sudiarta ${ }^{2}$, Putu Agus Wikanatha Sagita ${ }^{3}$ \\ 11Email: septiani575@gmail.com \\ Program Studi Industri Perjalanan Wisata, Fakultas Pariwisata, Universitas Udayana \\ 2Email: sudiarta.nyoman@yahoo.co.id \\ Program Studi Industri Perjalanan Wisata, Fakultas Pariwisata, Universitas Udayana \\ ${ }^{3}$ Email: wika.fpar@gmail.com \\ Program Studi Industri Perjalanan Wisata, Fakultas Pariwisata, Universitas Udayana
}

\begin{abstract}
The purpose of this research is to know the effectiveness of using Bali Go Live Channel as media promotion digital of Bali Tourism by using EPIC Model approach. Effectiveness measurement is done by obtaining value of empathy dimension, persuation dimension, impact dimension, and communication dimension from digital promotion conducted by Bali Go Live Channel to know how effective promotion is done. Determination of samples in this study using accidental sampling method as much as 100 respondents tourists. Data collection techniques used questionnaires and interviews. Data analysis technique in this research is quantitative descriptive analysis, validity and reliability analysis, simple tabulation analysis, and EPIC Model analysis. From the results of quantitative descriptive analysis can be seen that the measurement of dimensions empathy, dimension persuasion, dimension impact, and dimension communication entered in the range of effective scale. The results of this study show the use of Bali Go Live Channel as a digital promotion media of Bali tourism declared effective. This is shown from the EPIC Rate of 3.98 which fall into the effective category.
\end{abstract}

Abstrak: Tujuan penelitian ini adalah untuk mengetahui efektivitas penggunaan Saluran Bali Go Live sebagai media promosi digital pariwisata Bali dengan menggunakan pendekatan EPIC Model. Pengukuran Efektivitas dilakukan dengan cara mendapatkan nilai dimensi empathy, dimensi persuation, dimensi impact, dan dimensi communication dari promosi digital yang dilakukan oleh Saluran Bali Go Live untuk mengetahui seberapa efektif promosi yang dilakukan. Penentuan sampel dalam penelitian ini menggunakan metode accidental sampling sebanyak 100 responden wisatawan. Teknik pengumpulan data menggunakan kuesioner dan wawancara. Teknik analisis data dalam penelitian ini adalah analisis deskriptif kuantitatif, uji validitas dan realibilitas, analisis tabulasi sederhana, dan analisis EPIC Model. Dari hasil analisis deskriptif kuantitatif dapat diketahui bahwa Pengukuran dimensi empathy, dimensi persuasion, dimensi impact, dan dimensi communication masuk dalam rentang skala efektif. Hasil dari penelitian ini menunjukkan penggunaan Saluran Bali Go Live sebagai media promosi digital pariwisata Bali dinyatakan efektif. Hal ini ditunjukkan dari nilai EPIC Rate sebesar 3,98 yang masuk dalam kategori efektif.

Keywords: effectiveness, go live, promotion digital. 


\section{PENDAHULUAN}

Dewasa ini pengembangan industry pariwisata memberikan kontribusi yang positif bagi perekonomian dunia dan juga Indonesia. Pariwisata juga memberikan dampak positif terhadap bidang industri seperti terciptanya lapangan kerja dan lapangan usaha. Dalam mengembangkan pariwisata menjadi lebih baik secara kualitas dan dapat memberikan banyak pengaruh positif diperlukan adanya strategi untuk mencapainya.

Berbagai faktor penting perlu dilihat serta dilaksanakan demi tercapainya rencana pengembangan dan pembangunan yang tepat sasaran dan berkelanjutan, seperti perencanaan yang matang, strategi yang tepat guna dan sasaran, pembenahan objek wisata, fasilitas pelayanan hingga pemasaran pariwisata yang menjadi faktor penting dalam penunjang suatu pembangunan pariwisata.

Pemasaran pariwisata menjadi faktor penting dalam penunjang suatu pembangunan pariwisata karena pemasaran pariwisata adalah suatu proses manajemen yang dilakukan oleh organisasi pariwisata nasional atau perusahaan-perusahaan termasuk dalam kelompok industri pariwisata untuk melakukan identifikasi terhadap wisatawan yang sudah punya keinginan untuk melakukan perjalanan wisata dan wisatawan yang punya potensi untuk melakukan perjalanan wisata dengan jalan melakukan melakukan komunikasi dengan mereka, mempengaruhi keinginan, kebutuhan, memotivasinya terhadap apa yang disukai dan yang tidak disukainya, pada tingkat daerah-daerah lokal, regional, nasional ataupun internasional dengan menyediakan obyek dan atraksi wisata agar wisatawan memperoleh kepuasan optimal (Krippendorf, 1971:18 \& 34).

Dalam pemasaran, tentu adanya suatu proses promosi. Promosi adalah setiap upaya pemasaran yang fungsinya untuk memberikan informasi atau meyakinkan para konsumen yang potensial mengenai kegunaan suatu produk atau jasa dengan tujuan untuk mendorong konsumen baik melanjutkan atau memulai pembelian pada harga tertentu (Bahar, 2002: 103). Proses promosi tersebut dapat dilakukan dengan menggunakan berbagai media, seperti media cetak, media elektronik, maupun pameran.

Pada era modern saat ini, manusia tidak terlepas dari teknologi informasi dan menggiring kita masuk kedalam bagian dunia digital. Berdasar tren digital yang semakin berkembang, Kementerian Pariwisata Republik Indonesia melihat potensi media baru tersebut sebagai salah satu sarana promosi memasarkan beragam potensi wisata di tanah air. Menteri Pariwisata Arief Yahya menyatakan digital marketing sudah selayaknya digunakan oleh pelaku industri pariwisata sesuai dengan dinamika dan gaya hidup masyarakat. "Tren yang ada saat ini mengkondisikan para pelaku industri pariwisata untuk dapat melakukan pemasaran melalui digital marketing. Gaya hidup masyarakat yang bergerak cepat dan bersentuhan langsung dengan internet, menyebabkan model promosi tersebut sangat relevan diaplikasikan baik destinasi wisata maupun pengelola akomodasi pariwisata untuk melakukan pencitraan yang baik (republika.co.id).

Pulau Bali merupakan ikon pariwisata di Indonesia dan juga menjadi salah satu destinasi wisata tujuan wisatawan dunia. Dengan beraneka ragam keindahan sumber daya alam, seni dan budaya serta kekhasan dan keunikan tradisi masyarakat Bali, mampu memberikan daya tarik tersendiri kepada wisatawan baik wisatawan domestik maupun wisatawan mancanegara. Bali merupakan daerah tujuan wisata andalan di Indonesia yang sangat terkenal di dunia. Hal ini karena Bali memiliki berbagai obyek wisata alam yang indah dan bervariasi. Keindahan alam ini didukung oleh keunikan budaya Bali yang sangat erat dengan Agama Hindu. Kehidupan masyarakat Bali sangat dipengaruhi oleh budaya Hindu, baik dalam kegiatan keagamaan, kemasyarakatan, dan kesenian. Oleh karena itu, Bali memiliki keunikan tersendiri sehingga dapat menarik minat wisatawan untuk berkunjung ke Bali.

Pulau Bali seakan tidak pernah puas agar terus terkenal dan dikunjungi wisatawan nusantara dan mancanegara. Dalam upaya meningkatkan jumlah kunjungan wisatawan, Badan Promosi Pariwisata Daerah (BPPD) Bali bahkan kini mulai kembangkan media promosi pariwisata berbasis digital. Tak hanya sekedar promosi dengan kunjungan ke luar negeri, kali ini jalan yang ditempuh adalah digitalisasi visual. Pulau Bali yang dikenal sebagai Pulau Seribu Pura kini bekerjasama dengan saluran Bali Go Live (PT. Golive Media Internasional) untuk terus mempromosikan keindahan serta keunikan 
adat dan budaya masyarakat Bali. (Baliberkarya.com)

Badan Promosi Pariwisata Daerah (BPPD) Bali melihat pentingnya kerjasama atau kolaborasi dengan saluran Bali Go Live untuk menjawab tantangan digital marketing yang semakin kompleks. Saluran Bali Go Live mempromosikan Bali lewat platform digital populer Youtube dan memiliki website sendiri, juga didukung informasi terkini yang diunggah secara regular via media sosial seperti Facebook, Twitter, Instagram, Thumblr, dan Linkedin dengan menawarkan lima konten di antaranya culture and destination, commercial, lifestyle, back to Bali dan Virtual Reality 360-degree Video.

Kerjasama Badan Promosi Pariwisata Daerah (BPPD) dengan Bali Go Live ini merupakan langkah penting dalam pengembangan citra pariwisata Bali, karena peran BPPD Bali sebagai koordinator promosi pariwisata yang dilakukan dunia usaha di daerah dan mitra kerjasama pemerintah daerah menunjuk untuk meningkatkan metode pengembangan pasar kepariwisataan dan bisnis wisata Bali menuju pada level yang menyesuaikan dengan kecanggihan di era digital. Penandatanganan kerjasama antara pihak Bali Go Live dan BPPD Bali tersebut berlangsung di Taman Bhagawan, Tanjung Benoa, Bali pada tanggal 09 Mei 2016 yang dihadiri oleh Paulus Herry Arianto, MA dari pihak Bali Go Live dan Tjokorda Oka Artha Ardhana Sukawati (Cok Ace) dari pihak BPPD Bali. Turut hadir pula diantaranya beberapa tokoh industri pariwisata dan general manager hotel berbintang di Bali Kerjasama diharapkan dapat mengembangkan citra pariwisata Bali dengan meningkatkan metode pengembangan pasar kepariwisataan dan bisnis wisata di Pulau Dewata menuju peringkat yang menyesuaikan dengan kecanggihan di era digital serta meningkatkan jumlah kunjungan wisatawan ke Bali.

Kerja sama yang dilakukan Badan Promosi Pariwisata Daerah (BPPD) dengan saluran Bali Go Live dalam mempromosikan pariwisata Bali berbasis digital diharapkan akan menekan biaya promosi yang tinggi serta akan membuat sasaran promosi lebih efektif (kompas.com). Promosi dapat dikatakan efektif apabila adanya hubungan yang terjalin antara perusahaan dengan para konsumen dalam hal mengkomunikasikan produk, untuk mengetahui seberapa efektif suatu media promosi dalam mempromosikan suatu produk perlu adanya pengukuran efektivitas dari media atau iklan dalam mempromosikan suatu produk tersebut.

Pengukuran efektivitas juga merupakan salah satu tujuan dari promosi itu sendiri. Tujuan pertama adalah tujuan pemasaran. Dari tujuan ini, beberapa metode bisa diterapkan antara lain peningkatan volume penjualan, peningkatan marketshare, atau peningkatan keuntungan. Tujuan yang kedua, komunikasi, dapat juga menjadi basis untuk pengukuran efektifitas sebuah media promosi.

Pada dasarnya, metode ini menilai seberapa baik proses komunikasi tersampaikan dengan memanfaatkan model proses respon. Perencanaan dan pengendalian media promosi yang baik sangat tergantung pada ukuran efektivitas media promosi.

Beberapa hal menjadi alasan yang mendasari perlunya melaksanakan pengukuran efektifitas sebuah media promosi. Alasan-alasan tersebut antara lain adalah untuk menghindari kesalahan yang membawa konsekuensi kerugian finansial yang besar. Misalnya jika dari pengukuran efektifitas diketahui bahwa promosi tersebut tidak berhasil membujuk segmen konsumen yang ditargetkan, maka metode lain dapat segera dipertimbangkan Alasan lain adalah untuk mencari strategi alternatif dalam pemasaran yang lebih baik. Misalnya dari penelitian ini, jika dari pengukuran efektifitas diketahui bahwa performa Bali Go Live dalam mempromosikan pariwisata Bali yang dilakukan tidak lebih baik dari performa promosi pada media lainnya, maka Badan Promosi Pariwisata Daerah (BPPD) dapat mencari strategi alternativ dalam pemasaran yang lebih baik.

Oleh karena itu perlu adanya analisis mengenai efektivitas penggunaan saluran Bali Go Live sebagai media promosi digital pariwisata Bali sehingga dapat menjadi tolak ukur efektif atau tidaknya saluran Bali Go Live sebagai media promosi digital pariwisata Bali. Pengukuran efektivitas promosi diukur dengan menggunakan metode EPIC model yang ditemukan oleh lembaga riset dan penelitian AC. Nielsen. Model ini mengukur efektivitas promosi atau iklan terhadap dampak komunikasi mencakup empat dimensi kritis, yaitu, Empathy, Persuasion, Impact, dan Communication. 


\section{METODE}

Penelitian ini dilakukan untuk mengukur dan mengetahui efektivitas penggunaan saluran Bali Go Live sebagai media promosi pariwisata Bali berbasis digital.

Adapun variabel yang digunakan dalam penelitian ini adalah Efektivitas Promosi (X) yaitu kemampuan suatu promosi untuk menciptakan suatu sikap yang mendukung terhadap suatu produk dimana pesan suatu promosi dapat terpatri secara mendalam dalam benak konsumen, dan konsumen mencermatinya dengan sudut pandang yang benar. Empathy (X1) merupakan keadaan mental yang membuat seseorang mengidentifikasi dirinya atau merasa dirinya pada keadaan perasaan atau keadaan yang sama dengan orang atau kelompok lain. Dimensi empati dapat menggambarkan keadaan positif maupun negatif dari suatu kegiatan promosi. Persuasion (X2) adalah perubahan kepercayaan, sikap dan keinginan yang disebabkan oleh komunikasi promosi dan sesuatu yang dapat menarik seseorang untuk melakukan suatu hal tertentu. Impact (X3) Dimensi dampak menunjukkan apakah suatu produk bisa terlihat lebih menonjol daripada produk lain, dan apakah suatu promosi dapat mengikutsertakan konsumen dalam pesan yang disampaikan. Communication (X4) dimensi komunikasi memberikan informasi tentang kemampuan konsumen dalam mengingat pesan utama yang disampaikan, pemahaman konsumen, kekuatan kesan yang ditinggalkan dan kejelasan promosi.

Teknik pengumpulan data yang dilakukan dalam penelitian ini terdiri dari observasi, wawancara, studi kepustakaan serta kuesioner.

Adapun metode pengambilan sample responden yang digunakan dalam penelitian ini adalah non-probability sampling dengan prosedur accidental sampling, prosedur sampling yang memilih sampel orang atau unit yang paling mudah di jumpai atau diakses (W.Gulo,2012). Jumlah responden yang digunakan ialah sebanyak 100 responden yang terbagi kedalam wisatawan mancanegara dan domestik.

Teknik Analisis data menggunakan analisis deskriptif dengan pendekatan kuantitatif. Untuk mengukur keefektifan suatu promosi menggunakan EPIC Model dan hasil jawaban responden pada kuesioner selanjutnya menggunakan perhitungan skala likert untuk mengolah data.

\section{HASIL DAN PEMBAHASAN}

Gambaran Umum Saluran Bali Go Live

Saluran Bali Go Live merupakan satusatunya saluran video resmi Bali, yang mempromosikan Pariwisata Bali lewat platform digital social youtube dan website serta media social pendukung seperti Facebook, Twitter, Instagram, Tumblr, dan Linkedin yang berada di bawah pengelolaan PT. Golive Media Internasional yang terletak di J1. Yudistira 1 no. 1, Seminyak Kuta - Bali. Didirikan pada tahun 2015, Bali Go Live dibentuk sebagai sumber informasi yang lengkap berupa video untuk semua hal mengenai Bali, ensiklopedi bagi penonton yang berencana untuk berkunjung ke Bali.

Bali Go Live diproduksi oleh rumah produksi video paling profesional di Bali, AVB Media Asia. Sebagai perusahaan pembuat media terkemuka, badan video kreatif dan perusahaan produksi, AVB Media Asia percaya bahwa memberikan dampak nyata dan positif pada bidang film, video, multimedia dan fotografi dan memberikan solusi inspiratif sebagai pusat pengembangan media utama. AVB adalah perusahaan pembuatan media terkemuka, agen video kreatif dan perusahaan produksi yang berbasis di Bali. Kami percaya dalam memberikan dampak nyata dan positif, mendasar di bidang film, video, multimedia dan fotografi. Visi perusahaan adalah Memberikan solusi inspiratif sebagai pusat penciptaan media terkemuka.

CEO Bali Go Live, Paulus Herry Arianto menegaskankan Bali Go Live tidak cuma sekadar sebagai sarana promosi pariwisata Bali saja, tapi juga mendorong anak-anak muda Bali untuk lebih bangga pada filosofi dan budaya Bali sehingga nantinya dapat bercerita kepada seluruh dunia lewat media sosial. Contoh saja video tentang canang sari dan filosofinya yang dibuat Bali Go Live yang disajikan secara fun namun sangat informatif telah dilihat ribuan kali dan terus bertambah setiap harinya.

Bali Go Live sendiri telah berdiri sejak tahun 2015. Telah membuat begitu banyak video tentang pariwisata Bali sehingga boleh jadi merupakan ensiklopedia bagi wisatawan yang mencari tahu tentang Bali dari berbagai aspek, baik tujuan wisata, pilihan akomodasi 
dan transportasi, event yang perlu dikunjungi, lokasi hiburan dan juga tentang pengetahuan tradisi budaya Bali. Semuanya itu diupdate setiap minggu dengan format video berdurasi pendek dan dapat diakses gratis melalui Youtube dan media digital lainnya.

\section{Karakteristik Pengikut Saluran Bali Go Live}

Dari 100 responden dalam penelitian ini dibagi menjadi dua yaitu wisatawan mancanegara dan domestik.

Mayoritas pengikut atau responden saluran Bali Go Live yaitu wisatawan mancanegara yang mencapai jumlah 80 orang dengan presentase sebesar $80 \%$ berbanding dengan wisatawan domestik sejumlah 20 orang atau dengan presentase sebesar $20 \%$. Mayoritas pengikut atau responden saluran Bali Go Live yaitu wisatawan mancanegara laki-laki yang mencapai jumlah 41 orang berbanding dengan wisatawan domestik lakilaki sejumlah 6 orang atau dengan presentase sebesar $41 \%$ dan $6 \%$. Sedangkan presentase wisatawan wanita mancanegara sebesar 39\% (39 orang) dan wisatawan domestik wanita berjumlah $14 \%$ (14 orang).

Dari 100 responden yang digunakan dalam penelitian ini, dan yang mendominasi kewarganegaraan atau asal daerah dari pengikut atau responden saluran Bali Go Live yaitu wisatawan mancanegara asal wilayah atau benua Eropa dengan presentase mencapai $25 \%$ dibandingkan wisatawan domestik dengan presentase $20 \%$.

Responden yang berusia 25-44 tahun yang mendominasi pengikut atau responden saluran Bali Go Live dengan presentase sebesar $45 \%$ atau sebanyak 45 responden wisatawan mancanegara dan 7 responden $(7 \%)$ merupakan wisatawan domestik. Pelajar merupakan yang mendominasi pengikut atau responden saluran Bali Go Live dengan presentase sebesar $45 \%$ atau sebanyak 45 responden terdiri dari 14 wisatawan domestik dan 31 wisatawan mancanegara. yang berstatus single merupakan yang mendominasi pengikut atau responden saluran Bali Go Live dengan presentase sebesar $65 \%$ atau sebanyak 65 responden terdiri dari 17 wisatawan domestik dan 48 wisatawan mancanegara.

Responden yang memilik pendidikan terakhir diploma merupakan yang mendominasi pengikut atau responden saluran
Bali Go Live dengan presentase sebesar 38\% atau sebanyak 38 responden terdiri dari 11 wisatawan domestik dan 27 wisatawan mancanegara.

Wisatawan yang berkunjung 2-5 kali ke Bali merupakan yang mendominasi pengikut atau responden saluran Bali Go Live dengan presentase sebesar $47 \%$ atau sebanyak 47 responden terdiri dari 13 wisatawan domestik dan 34 wisatawan mancanegara.Wisatawan yang berkunjung ke Bali dengan tujuan Berlibur merupakan yang mendominasi pengikut atau responden saluran Bali Go Live dengan presentase sebesar $95 \%$ atau sebanyak 95 responden terdiri dari 20 wisatawan domestik dan 75 wisatawan mancanegara.

Responden yang tidak mengakses saluran Bali Go Live untuk pertama kalinya merupakan yang mendominasi pengikut atau responden saluran Bali Go Live dengan presentase sebesar $58 \%$ atau sebanyak 58 responden terdiri dari 13 wisatawan domestik dan 45 wisatawan mancanegara. Responden yang mengakses saluran Bali Go Live sebanyak 2-5 kali ke Bali merupakan yang mendominasi pengikut atau responden saluran Bali Go Live dengan presentase sebesar $49 \%$ atau sebanyak 49 responden terdiri dari 12 wisatawan domestik dan 37 wisatawan mancanegara. Angka tersebut lebih tinggi dibandingkan responden yang mengakses saluran Bali Go Live sebanyak 1 kali yang berjumlah 40 responden (40\%). Responden yang mengakses saluran Bali Go Live melalui social media merupakan yang mendominasi pengikut atau responden saluran Bali Go Live dengan presentase sebesar $54 \%$ atau sebanyak 54 responden terdiri dari 13 wisatawan domestik dan 41 wisatawan mancanegara.

Uji validitas dalam penelitian ini digunakan untuk mengukur valid atau tidaknya butir instrument atau indikator yang digunakan dalam kuesioner. Hal tersebut penting dilakukan karena berkaitan dengan keakuratan sebuah data. Uji validitas dalam penelitian ini dikatakan valid apabila koefisien korelasi sama dengan 0,5 atau lebih (paling kecil 0,5).

Berdasarkan hasil uji validitas dapat dinyatakan bahwa semua indikator yang telah diuji adalah valid, hal tersebut terjadi karena nilai dari masing-masing indikator mempunyai nilai korelasi lebih besar dari 0,5 (Kriyantono, 2006: 173).

Untuk pengukuran atau uji reliabilitas 
dalam penelitian ini dilakukan dengan pengukuran sekali saja atau one shoot. Pengukuran reliabilitas tersebut dibandingkan dengan pertanyaan lain atau mengukur reliabilitas dengan uji statistik Cronbach Alpha (a). Apabila nilai Cronbach Alpha (a) $>$ 0,7 maka variabel yang diuji reliable. Dari hasil uji reliabilitas dapat disimpulkan bahwa pada pengujian reliabilitas dengan total 100 responden diperoleh nilai alpha cronbach 0,870 artinya hasil tersebut telah memenuhi syarat reliabel yaitu $>0,7$

\section{Efektivitas Penggunaan Saluran Bali Go Live}

Pengukuran efektivitas saluran Bali Go Live sebagai media promosi digital pariwisata Bali dilakukan dengan menganalisa pertanyaan dan jawaban dari pengunjung yang ada pada kuesioner. Penelitian dilakukan untuk mendapatkan nilai dimensi empathy, dimensi persuation, dimensi impact, dan dimensi communication dari promosi digital yang dilakukan oleh Saluran Bali Go Live.

\section{Analisis Dimensi Empathy}

Berdasarkan hasil analisis tampak bahwa: Dimensi empathy 1 dan 2 yakni "Informasi pariwisata Bali di Saluran Bali Go live sangat bagus dan saya menyukai informasi yang ada di saluran Bali Go Live " mempunyai skor rata-rata 4,00 dan 3,96. disimpulkan bahwa promosi yang dilakukan saluran Bali Go Live sangat bagus sehingga responden menyukai informasi pariwisata Bali di Saluran Bali Go Live. Dimensi empathy 3 yakni "Informasi yang sangat bagus menjadikan saya ingin melihat postingan Saluran Bali Go Live" dengan skor rata-rata 4,00. Disimpulkan bahwa responden memiliki respon yang baik terhadap postingan informasi pariwisata Bali yang di sajikan Saluran Bali Go Live.

Hasil analisis pengukuran efektivitas dimensi empathy pada Saluran Bali Go Live menunjukkan bahwa promosi digital yang dilakukan tersebut termasuk dalam rentang skala efektif dengan rata-rata berbobot 3,98 yang berarti promosi berbasis digital ini membuat responden merasakan reaksi positif terhadap informasi yang di sampaikan oleh saluran Bali Go Live, serta mampu menciptakan hubungan antar konsumen dengan produk melalui isi pesan yang relevan secara personal. Hal ini mengindikasikan bahwa promosi berbabis digital yang dilakukan oleh saluran Bali Go Live tersebut mampu memberikan informasi ataupun pesan yang menarik dalam bentuk video maupun photo tersebut sehingga cukup disukai oleh konsumen.

\section{Analisis Dimensi Persuassion}

Berdasarkan hasil analisis tampak bahwa: Dimensi persuassion 1 "Konten Saluran Bali Go Live membuat saya ingin mengetahui tentang pariwisata Bali lebih jauh." mempunyai skor rata-rata 4,00. disimpulkan bahwa promosi yang dilakukan saluran Bali Go Live mampu mempengaruhi pengunjungnya untuk tertarik kepada produk yang ditawarkan dilihat dari tanggapan responden yang ingin mengetahui tentang pariwisata Bali lebih jauh karena melihat konten yang ada di Saluran Bali Go Live. Dimensi persuassion 2 yakni "Konten Saluran Bali Go Live yang menarik, menjadikan saya ingin mengunjungi Bali." dengan skor rata-rata 4,01. disimpulkan bahwa promosi yang dilakukan saluran Bali Go Live mampu mempengaruhi pengunjungnya untuk mencoba produk yang ditawarkan, dilihat dari tanggapan reponden yang ingin mengunjungi Bali karena konten Saluran Bali Go Live yang menarik.

Hasil analisis pengukuran efektivitas dimensi persuassion pada Saluran Bali Go Live menunjukkan bahwa promosi digital yang dilakukan oleh Saluran Bali Go Live termasuk dalam rentang skala efektif dengan rata-rata berbobot 4,00 dimana promosi yang dilakukan saluran Bali Go Live mampu mempengaruhi pengunjungnya untuk tertarik kepada produk yang ditawarkan dilihat dari tanggapan responden yang ingin mengetahui tentang pariwisata Bali lebih jauh karena melihat konten yang ada di Saluran Bali Go Live. Serta mampu mempengaruhi pengunjungnya untuk mencoba produk yang ditawarkan dilihat dari tanggapan reponden yang ingin mengunjungi Bali karena konten Saluran Bali Go Live yang menarik.

\section{Analisis Dimensi Impact}

Berdasarkan hasil analisis tampak bahwa : Dimensi impact 1 dan 2 "Saya mengetahui informasi tempat wisata menarik yang ada di Bali melalui Saluran Bali Go Live." dan "Saya mengerti Pariwisata Bali 
dengan baik melalui Saluran Bali Go Live" mempunyai skor rata-rata 3,97 dan 3,95. disimpulkan bahwa promosi yang dilakukan saluran Bali Go Live mampu memberikan dampak kepada responden.

Hasil analisis pengukuran efektivitas dimensi impact pada Saluran Bali Go Live menunjukkan bahwa promosi digital yang dilakukan tersebut termasuk dalam rentang skala efektif dengan rata-rata berbobot 3,96 dimana promosi yang dilakukan saluran Bali Go Live mampu memberi dampak kepada responden dilihat dari responden yang mengetahui informasi tempat wisata menarik yang ada di Bali melalui Saluran Bali Go Live dan mengerti Pariwisata Bali dengan baik melalui Saluran Bali Go Live.

\section{Analisis Dimensi Communication}

Berdasarkan hasil analisis tampak bahwa : Dimensi communication 1 dan 2 "Informasi yang ada di saluran Bali Go Live sangat jelas." dan "Informasi yang ada di saluran Bali Go Live mudah untuk dipahami " mempunyai skor rata-rata 3,99 dan 4,03. disimpulkan bahwa promosi yang dilakukan saluran Bali Go Live mampu mengkomunikasikan pesannya dengan baik kepada konsumennya. Dimensi communication 3 "Saya dapat membayangkan bagaimana pariwisata Bali setelah menelusuri saluran Bali Go Live dan memahami informasi yang ada di Saluran Bali Go Live." mempunyai skor rata-rata 4,03. disimpulkan bahwa promosi yang dilakukan saluran Bali Go Live mampu mengkomunikasikan pesannya dengan baik kepada konsumennya.

Hasil analisis pengukuran efektivitas dimensi communication pada Saluran Bali Go Live menunjukkan bahwa promosi berbasis digital yang dilakukan tersebut termasuk dalam rentang skala efektif dengan rata-rata berbobot 4,00 dimana promosi yang dilakukan saluran Bali Go Live mampu mengkomunikasikan pesannya dengan baik kepada konsumennya.

\section{Analisis EPIC Rate}

Setelah masing-masing dimensi diperoleh hasilnya, lalu dicari nilai rata-rata EPIC rate. Ke empat nilai dimensi tersebut dijumlahkan untuk mendapatkan nilai rata-rata guna mendapatkan nilai EPIC rate. Secara keseluruhan tabel skor dari keempat dimensi dapat dilihat pada tabel 4.8. Perhitungan keempat dimensi tersebut adalah sebagai berikut:

Tabel 1. Hasil Analisis EPIC Rate

\begin{tabular}{llcl}
\hline NO & Epic Model & Skor & Kesimpulan \\
\hline 1 & Empathy & 3,98 & Efektif \\
\hline 2 & Persuasion & 4,00 & Efektif \\
\hline 3 & Impact & 3,96 & Efektif \\
\hline 4 & Communication & 4,00 & Efektif \\
\hline Rata - Rata & 3,98 & Efektif \\
\hline
\end{tabular}

Sumber: Hasil Penelitian, 2017.

$$
\begin{aligned}
\text { EPIC Rate } & =\frac{3,98+4,00+3,96+4,00}{4} \\
& =3,98
\end{aligned}
$$

Skala Penilaian:

$1,00<\mathrm{x} \leq 1,80=$ Sangat tidak efektif

$1,80<\mathrm{x} \leq 2,60=$ Tidak efektif

$2,60<\mathrm{x} \leq 3,40=$ Cukup efektif

$3,40<\mathrm{x} \leq 4,20=$ Efektif

$4,20<x \leq 5,00=$ Sangat efektif

Berdasarkan perhitungan, hasil akhir dari nilai EPIC rate adalah 3,98 yang jika dimasukkan kedalam skala penilaian termasuk dalam kategori efektif. Hal ini memperlihatkan bahwa penggunaan saluran Bali Go Live sebagai media promosi digital pariwisata Bali sudah efektif serta dapat mengkomunikasikan informasi pariwisata Bali dengan baik kepada konsumen, namun saluran Bali Go Live masih sangat perlu memaksimalkan dalam hal mengkomunikasikan informasi pariwisata Bali melihat skor dimensi empathy dan impact memiliki rata rata dibawah 4,00 hal tersebut dikarenakan menurut komentar responden saluran Bali Go Live yang peneliti amati selama penelitian mengatakan bahwa terkadang saluran Bali Go Live mengunggah informasi yang sudah di unggah sebelumnya, jadi informasi yang disampaikan terkesan monoton sehingga membuat dimensi empathy dan impact memiliki rata rata dibawah 4,00.

Secara keseluruhan grafik hasil analisis efektivitas penggunaan saluran Bali Go Live sebagai media promosi pariwisata Bali berbasis digital dengan menggunakan metode EPIC Model tersaji pada gambar 1 . 


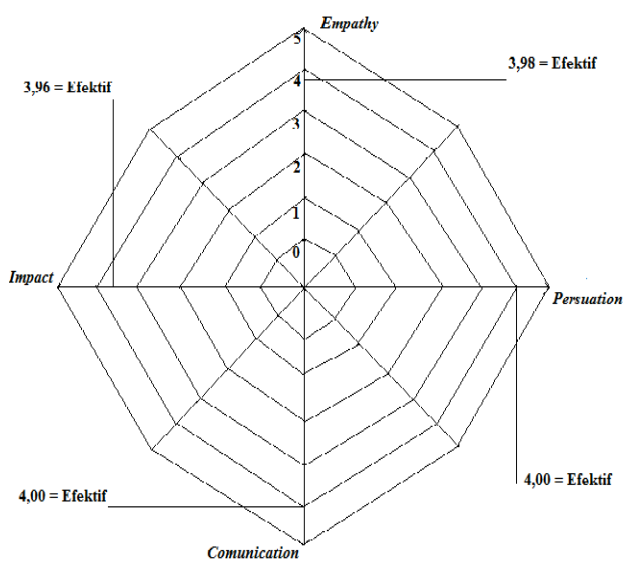

Gambar 1. EPIC Model Saluran Bali Go Live

Sumber: Hasil Penelitian, 2017

\section{SIMPULAN DAN SARAN Simpulan}

Berdasarkan hasil penelitian maka dapat disimpulkan bahwa pengukuran dimensi empathy menunjukkan bahwa promosi ini masuk dalam rentang skala efektif dengan skor rataa-rata 3,98. Hal ini menunjukkan bahwa promosi tersebut mampu memberikan informasi dan pesan yang menarik dalam promosi tersebut sehingga cukup disukai oleh konsumen.

Pengukuran dimensi persuasion menunjukkan bahwa promosi ini masuk dalam rentang skala efektif dengan skor ratarata 4,00. Hal ini mengindikasikan bahwa promosi berbasis digital yang dilakukan oleh Saluran Bali Go Live cukup dapat meningkatkan dan menguatkan informasi pariwisata Bali dalam benak konsumen. Promosi tersebut cukup memiliki dampak terhadap keinginan konsumen untuk mengunjungi Bali setelah melihat informasi pariwisata Bali yang dipromosikan oleh Saluran Bali Go Live.

Pengukuran dimensi impact menunjukkan bahwa promosi ini masuk dalam rentang skala efektif dengan skor ratarata 3,96. Hal ini menunjukkan bahwa promosi tersebut cukup menonjol dalam memberi pengetahuan mengenai informasi Pariwisata Bali yang disajikan.

Pengukuran dimensi communication menunjukkan bahwa promosi ini masuk dalam rentang skala efektif dengan skor rata-rata 4,00. Hal ini menunjukkan bahwa promosi tersebut cukup baik dalam menyampaikan informasi kepada konsumen.

\section{Saran}

Berdasarkan hasil penelitian dan pembahasan diatas maka dapat dikemukakan saran kepada pihak pengelola saluran Bali Go Live dan juga akademisi sebagai berikut:

PT. Golive Media Internasional harus lebih memperhatikan postingan yang disampaikan dalam mempromosikan pariwisata Bali melalui saluran Bali Go Live agar pesan mampu mendapat perhatian, pemahaman, menggugah perasaan dan kemampuan pesan untuk mempengaruhi perilaku konsumen ataupun memberi dampak terhadap konsumen sehingga akhirnya menggunakan jasa yang ditawarkan yang dimaksud disini mampu mempengaruhi wisatawan mengunjungi Bali melihat skor dimensi empathy dan impact memiliki rata rata dibawah 4,00.

PT. Golive Media Internasional harus lebih memperhatikan kualitas postingan yang berfungsi untuk mempromosikan pariwisata Bali. Postingan sebaiknya memberikan informasi yang lebih jelas bagi konsumen bukan hanya sekedar tampilan kreatif yang disajikan melalui website ataupun media sosial tapi juga tidak melupakan tujuan dari promosi itu sendiri.

PT. Golive Media Internasional harus lebih memperhatikan unggahan informasi pariwisata Bali yang akan di publish agar tidak terjadi informasi pariwisata yang di unggah berulang kali sehingga membuat pendapat pengguna saluran Bali Go Live memberikan informasi yang monoton. 


\section{Kepustakaan}

Bahar. 2002. Pengantar Pariwisata. Bandung:

Alfabeta.

http://www.antaranews.com/berita/559946/bal i-go-live-wisata-digital-ke-pulau-dewata 20:3419 oktober 2016.

http://poskotanews.com/2016/05/14/promosiwisata-bppd-bali-go-live-sebar-jaringgo-digital/ 20:2019 oktober 2016.

http://www.republika.co.id/berita/kemenpar/be rita-kemenpar/16/09/07/od3qp9280menpar-sudah-seharusnya-promosipariwisata-melalui-digital-marketing 21:0019 oktober 2016.

Krippendorf, J. 2011. Marketing Et Tourisme.

Kriyantono, Rachmat.2006. Teknik Praktis Riset Komunikasi. Jakarta: Kencana.

Gulo, W. 2010. Metodologi Penelitian.Jakarta: PT. Gramedia. 